\title{
Profile of dentists in oral health team of a microregion of Minas Gerais, Brazil
}

\author{
Perfil dos cirurgiões-dentistas da equipe de saúde bucal de uma microrregião de saúde de Minas Gerais, \\ Brasil
}

Grazielle Christine Maciel MATTOS

Efigênia Ferreira e FERREIRA ${ }^{1}$

Ana Cristina Viana CAMPOS ${ }^{1}$

Isabel Cristina Gonçalves LEITE²

Rosângela Maria GRECO ${ }^{3}$

\section{ABSTRACT}

\section{Objective}

To describe the profile of dentists in oral health team of the micro-region of Minas Gerais, Brazil.

\section{Methods}

Cross-sectional study with 48 dentists in 16 municipalities, in which data collection was conducted by questionnaire. The variables considered for the study were: training time in years, and monthly real salary (centroid), in compliance with weekly working hours, mode of incorporation into the oral health team, postgraduate course, social participation and ongoing involvement in Family Health. All variables were used to group dentists by Two Step Cluster analysis segmentation, with $p<0.05$ significance level.

\section{Results}

They formed three clusters that differed mainly in relation to training time in years $(p=0.007)$, hours worked $(p<0.001)$, postgraduate course $(p<0.001)$ and social participation $(p=0.031)$. The first cluster grouped dentists with less training time, receiving an intermediate salary to comply with the stated working hours and lack of post-graduate course, the second grouped dentists with the highest salaries and years of graduation who have post-graduate course and the last was composed of dentists with intermediary training time, the lowest salaries that complied with the working hours, have attended the training course / training in the Family Health Strategy and have no social participation.

\section{Conclusion}

Dentists in the Family Health Strategy differ as regards weekly working hours, postgraduate course and social participation in the city, and the training time can be a critical feature to point out these differences.

Indexing terms: Occupational dentistry. Occupational health. Oral health.

\section{RESUMO}

\section{Objetivo}

Descrever o perfil dos cirurgiões-dentistas da equipe de saúde bucal de uma microrregião de saúde de Minas Gerais, Brasil.

\section{Métodos}

Estudo transversal com 48 cirurgiões-dentistas de 16 municípios, cuja coleta de dados foi realizada por questionário. As variáveis consideradas foram: tempo de formação em anos e salário mensal em reais (centroides), cumprimento da jornada de trabalho semanal, modalidade de incorporação na equipe de saúde bucal, curso de pós-graduação, participação social e participação em curso na Saúde da família. Todas as variáveis foram utilizadas para agrupar os cirurgiões-dentistas por meio da análise de segmentação TwoStep Cluster com distância euclidiana quadrática, com $\mathrm{p}<0,05$ de significância.

\section{Resultados}

Formaram-se três clusters que se diferenciam principalmente em relação ao tempo de formação profissional $(p=0,007)$, jornada cumprida de trabalho $(p<0,001)$, pós-graduação $(p<0,001)$ e participação social $(p=0,031)$. O primeiro reuniu cirurgiões-dentistas com menor tempo de formação, salário intermediário que declararam cumprir a jornada de trabalho e que não possuem curso de pós-graduação; o segundo reuniu cirurgiões-dentistas com os maiores salários e tempo de formado que possuem curso de pós-graduação e o último foi formado por cirurgiõesdentistas com tempo de formação intermediário, os menores salários, que cumprem a jornada de trabalho, já realizaram curso de capacitação/ treinamento na Estratégia Saúde da Família e não tem participação social.

\section{Conclusão}

Os cirurgiões-dentistas da Estratégia Saúde da Família são diferentes em relação à jornada de trabalho semanal, curso de pós-graduação e participação social no município, sendo que o tempo de formação pode ser uma característica crucial para apontar essas diferenças.

Termo de indexação: Odontologia do trabalho. Saúde do trabalhador. Saúde bucal.

\footnotetext{
${ }^{1}$ Universidade Federal de Minas Gerais, Faculdade de Odontologia, Departamento de Odontologia Social e Preventiva. Av. Antônio Carlos, 6627, Pampulha, 31270-901, Belo Horizonte, MG, Brasil. Correspondência para / Correspondence to: GCM MATTOS. E-mail: <gueziabh@yahoo.com.br>.

${ }^{2}$ Universidade Federal de Juiz de Fora, Faculdade de Medicina, Departamento de Saúde Coletiva. Juiz de Fora, MG, Brasil.

${ }^{3}$ Universidade Federal de Juiz de Fora, Faculdade de Enfermagem, Departamento de Enfermagem Básica. Juiz de Fora, MG, Brasil.
} 


\section{INTRODUCTION}

The practice of dentistry is still centered on the complaint-procedure care approach, in spite of it being inefficient and ineffective. Ineffective because, at significant levels, it does not respond to the population's health problems, and inefficient, since it is a high cost and extremely low yield approach'1. This underlies the importance of including dentistry in the Brazil's Unified Health System, seeking new ways of organizing the service and improving the oral health conditions of the population².

The inclusion of Dentistry in the Family Health Strategy (FHS) has been seen as the possibility of breaking with these models of care 3 . The "Smiling Brazil" ("Brasil Sorridente") project launched in 2004 greatly increased the capacity and quality of care; the implementation of dental prosthesis laboratories throughout the Country, making dental prostheses available in the basic care network, extending candy qualifying basic care; and the inclusion of dental inputs in the basic pharmacy of the Family Health Program ${ }^{4}$.

This concerns a change in paradigm, a different view of health care that seeks to see the subject as a whole. The actions of the health team seek to prioritize health promotion, prevention of oral diseases, resolutions of existent oral health-disease problems, based on integrality, seeking to organize care by actively finding families and promoting changes in the work process ${ }^{5-6}$.

The merely clinical and punctual attendance may be explain by the professional profile being focused on the clinical approach, influence of a Flexerian education, and by the expectation of the community, accustomed to the professional's curative attendance. From this aspect, the study of the profile of dentists included in the Oral Health Team involves the important task of understanding the social, cultural and economic realities of their environment and of directing their actions to change these aspects to benefit the population?

In this context, the aim of this study was to describe the profile of dentists in the oral health team of a micro-health-region in Minas Gerais.

\section{METHODS}

This was a cross-sectional study with 48 dentists in a micro-health-region in Minas Gerais.

This microregion has a population of around 271,000 inhabitants, an area of approximately 4,900 km² and belongs to the mesoregion of the forest region "Zona da Mata". From among the 24 municipalities belonging to the microregion, 20 were selected to participate in the study, and four municipalities did not accept the invitation. The inclusion criterion established was to have an oral health team included in the Family Health Strategy, with a minimum period of two years of implementation in February 2009. This cut-off point was considered the minimum sufficient for finding a change in the model of care, seeing that changes in a model depend on, among other factors, the political context, organization of the services, training processes and involvement of the team.

A pilot study was conducted in a municipality belonging to the microregion, which was excluded from the sample. This study was conducted two months before data collection began, and no need was found to make changes in the questionnaire.

Data was collected by means of a questionnaire constructed especially for this research. The variables considered for the study were as follows: Time since graduation; monthly salary in Reais; compliance with the weekly working hours (yes, no), modality of incorporation into the Oral Health Team (indication, others), having a post-graduate course (yes, no), social participation (yes, no) and participation in qualification/training in Family Health (yes, no).

To verify whether there were differences among the dentists with regard to the professional profile, an analysis by the Two Step Cluster segmentation method with quadratic Euclidian distance was performed ${ }^{8}$, which divided the participants into three distinct groups. This analysis is a statistical tool with the main object of allocating more similar cases into the same cluster, based on the characteristics according to which the data were measured.

The database and all the analyses were performed using the Software Package for Social Sciences for Windows (SPSS) version 17. After performing a descriptive analysis, all the variables described above were used to form the clusters, with the time since graduation and salary being selected by the program as being centroids. In this type of analyses, the Adjusted Bonferroni and ANOVA tests were sued to measure the weight of the variables and the external differences between the clusters formed, with a level of significance of $p<0.05$.

All the participants were given complete information about the research and agreed to sign the Term of Free and Informed Consent. Development of the research was approved by the Research Ethics Committee of the Federal University of Juiz de Fora in accordance with report No. 021/2009, with a view to complying with the ethical principles contained in the Helsinki Declaration? 


\section{RESULTS}

The majority of dentists had worked for the Family Health Strategy for over five years (51.00\%), were indicated to work in the Oral Health Team (58.33\%), had no social participation in the municipality (54.17\%), but had participated in the qualification and/or training courses after entering the Family Health Strategy (54.20\%). Moreover, $47.92 \%$ of them do not fulfill the weekly working hours.

The segmentation analysis resulted in three clusters, with 11 dentists not being grouped in any of the clusters. The first cluster grouped dentists with the shortest time since graduation, intermediate salary, who declared that they fulfilled the working hours, and that they had not done a post-graduate course. The second cluster grouped the dentists with the highest salaries and longest time since graduation, and who had done a post-graduation course. The last cluster was formed by dentists with an intermediate time since graduation, the lowest salaries, who fulfilled the working hours, had done a qualification/ training course in the Family Health Strategy, and who had no social participation (Table 1).

The mean values of time since graduation in clusters 1,2 and 3 were $2.82( \pm 2.74), 10.45( \pm 7.82)$ and $5.10( \pm 4.67)$, respectively. As regards salary, the mean values found were $R \$ 2,146.18( \pm 287.83), R \$ 2,187.27$ $( \pm 653.58)$ and $R \$ 1.733 .92( \pm 305.31)$. The results of the One-way ANOVA test revealed that there were statistically significant differences between the clusters with regard to the centroids - time since graduation $(p=0.007)$ and salary $(p=0.019)$.

Afterwards, the Tukey HDS test was applied to identify the differences between clusters two by two. The dentists in clusters 1 and 2 differed significantly with regard to time since graduation $(p=0.006)$, while clusters 2 and 3 presented significant difference with regard to both time since graduation $(p=0.045)$ and salary $(p=0.033)$ (Table 2$)$.

Table 3 shows that the three clusters differed statistically with regard to working hours $(p<0.001)$, post-graduation course $(p<0.001)$, social participation $(p=0.031)$ and qualifications and/or training $(p=0.031)$. In cluster 1, all the dentists affirmed that they fulfilled the working hours, while in cluster 3 none of the dentists fulfilled this requirement. When comparing clusters 1 and 2 , one perceives that in the first, no dentists had done a post-graduation course, and in the second, all the dentists affirmed that they were post-graduates.
Table 1. Description of the clusters formed with the similar characteristics in each cluster Microregion of health in Minas Gerais, Brazil (2009).

\begin{tabular}{lc}
\hline Cluster & Similar characteristics \\
\hline $1(n=11) \quad \begin{array}{c}\text { Shorter time since graduation } \\
\text { Mean salary }\end{array}$ \\
$\begin{array}{c}\text { Fulfilled the working hours foreseen } \\
\text { Did not do a post-graduation course } \\
\text { Longer time since graduation } \\
\text { Better salary } \\
\text { Did do a post-graduation course } \\
\text { Intermediate time since graduation } \\
\text { Lualification courses in service/training in Family Health Strategy } \\
\text { Without social participation }\end{array}$ \\
\hline
\end{tabular}

Table 2. Distribution of differences in means, standard deviation and interval of confidence of $95 \%$ of time since graduation and monthly salary among clusters. Microregion of health in Minas Gerais, Brazil (2009).

\begin{tabular}{|c|c|c|c|c|c|c|c|}
\hline \multirow{2}{*}{ Variables } & \multirow{2}{*}{\multicolumn{2}{|c|}{ Cluster }} & \multirow{2}{*}{$\begin{array}{l}\text { Difference } \\
\text { among } \\
\text { the means }\end{array}$} & \multirow{2}{*}{$\begin{array}{l}\text { Standard } \\
\text { deviation }\end{array}$} & \multicolumn{2}{|c|}{ IC $95 \%$} & \multirow{2}{*}{$p$-value* } \\
\hline & & & & & Beginning & Final & \\
\hline \multirow{4}{*}{$\begin{array}{l}\text { Time since } \\
\text { graduation }\end{array}$} & \multirow{2}{*}{1} & 2 & -7.64 & 2.30 & -13.28 & -1.99 & 0.006 \\
\hline & & 3 & -2.28 & 2.15 & -7.54 & 2.98 & 0.543 \\
\hline & \multirow{2}{*}{3} & 1 & 2.28 & 2.15 & -2.98 & 7.54 & 0.543 \\
\hline & & 2 & -5.36 & 2.15 & -10.61 & -0.10 & 0.045 \\
\hline \multirow{4}{*}{ Salary } & \multirow{2}{*}{1} & 2 & $-41,09$ & 185.07 & -494.60 & 412.42 & 0.973 \\
\hline & & 3 & 412,27 & 172,29 & $-9,93$ & 834.46 & 0.057 \\
\hline & \multirow{2}{*}{3} & 1 & -412.27 & 172.29 & -834.46 & 9.93 & 0.057 \\
\hline & & 2 & -453.36 & 172.29 & -875.55 & -31.16 & 0.033 \\
\hline
\end{tabular}

*Tukey HDS Test.

Table 3. Distribution of clusters as regards variables corresponding to professional profile of dentists Microregion of health in Minas Gerais, Brazil (2009).

\begin{tabular}{|c|c|c|c|c|c|c|c|}
\hline \multirow{3}{*}{$\begin{array}{l}\text { Variables } \\
\text { Categories }\end{array}$} & \multicolumn{6}{|c|}{ Clusters } & \multirow{4}{*}{ p-value* } \\
\hline & \multicolumn{2}{|c|}{1} & \multicolumn{2}{|c|}{2} & \multicolumn{2}{|c|}{3} & \\
\hline & $n$ & $\%$ & $n$ & $\%$ & $n$ & $\%$ & \\
\hline \multicolumn{7}{|c|}{ Fulfill the working hours } & \\
\hline Yes & 11 & 100.0 & 8 & 72.7 & 0 & 0.00 & \multirow{2}{*}{$<0.001$} \\
\hline No & 0 & 0.00 & 3 & 27.3 & 15 & 100.0 & \\
\hline \multicolumn{8}{|c|}{ Incorporation into Oral Health Team } \\
\hline Indication & 7 & 63.64 & 6 & 54.55 & 12 & 80.0 & \multirow{2}{*}{0.370} \\
\hline Others & 4 & 36.36 & 5 & 45.45 & 3 & 20.0 & \\
\hline \multicolumn{8}{|c|}{ Social participation } \\
\hline Yes & 2 & 18.18 & 7 & 63.64 & 3 & 20.0 & \multirow{2}{*}{0.031} \\
\hline No & 9 & 81.82 & 4 & 36.36 & 12 & 80.0 & \\
\hline \multicolumn{8}{|c|}{ Post-graduation course } \\
\hline Yes & 0 & 0.00 & 11 & 100.0 & 9 & 60.0 & \multirow{2}{*}{$<0.001$} \\
\hline No & 11 & 100.0 & 0 & 0.00 & 6 & 40.0 & \\
\hline \multicolumn{8}{|c|}{ Qualification and/or training } \\
\hline Yes & 9 & 81.82 & 4 & 36.36 & 12 & 80.0 & \multirow{2}{*}{0.031} \\
\hline No & 2 & 18.18 & 7 & 63.64 & 3 & 20.0 & \\
\hline
\end{tabular}




\section{DISCUSSION}

The Family Health Strategy seeks to defend multidisciplinary work with focus on the nuclear family; to integrate the individual in the collective society, and use Epidemiology as a decision-making tool, guided by the criteria or prioritization, based on the concept of risk ${ }^{10}$. Oral health is still included in Family Health in a rudimentary manner, developing a predominantly curative-restorative practice instead of collective actions, without interaction with the other areas of knowledge and subjects of the team ${ }^{10-11}$. This is frequently due to the professional profile being essentially focused on clinical activities.

The majority of the professionals in this study are working under contract $(58.33 \%)$. In a research of national scope, it was found that in the major portion of the municipalities, workers are hired via the municipalities, with temporary contracts, or supply of services being the main form of hiring workers for the Family Health Strategy and Oral Health Team, which weakens the professional tie $^{12}$.

In the present study, almost half of the dentists affirmed that they do not fulfill the working hours. The professionals who compose the Family Health Strategy must know the community in which they are working, their needs and vulnerabilities, in order to reinforce ties, creating possibility to enable them to act in health promotion and prevention. It is not possible to form this fundamental tie when the professional does not stay in the service permanently ${ }^{5,12}$.

From the centroids, the differences between the participants began to appear. Cluster 1 was formed by 11 dentists with the fewer than three years of time since graduation, who fulfilled the working hours, and had not done a post-graduate course. In the second cluster, there were dentists who had done a post-graduation course, had the longest time since graduation, and the highest salaries. The largest Cluster was formed by 15 dentists who essential did not fulfill the working hours, received the lowest salary and had over 5 years of time since graduation.

The results of the study showed a professional profile which is not compatible with the model of health in force in Brazil, recommended by Family Health ${ }^{13-17}$. The hegemony of the private sector appears to have an influence of the professional practice of the dentists in public service ${ }^{18}$.

The contradictions in Brazilian dentistry, observed from the analytical perspective of Sociology, reflect and reproduce the current dilemmas of a model of education and dental practice immersed in complex transition. The passage of market Dentistry, of a liberal and private nature, typical of the last decades of the Twentieth Century, to a Dentistry subject to the oscillations of job offer and income, in an extremely competitive market, is the modern tonic ${ }^{19}$.

The proposals for collective oral health practice are in frontal opposition to the hegemony of this market, liberal and private dentistry. Collective oral health has sought to constitute itself with reference to a practice for work in dentistry, capable of recovering its political, social, community, preventive and integral dimensions, indispensible to practices in the field of health, whose horizons are democratic and solidary societies, in which the questions of health-disease effectively are of public relevance, and are thus considered by the State and the set of society ${ }^{20}$.

Although there were significant differences between clusters 1 and 2 ( $p=0.006)$, and 3 and 2 ( $p=0.045$ ) for the time since graduation, this aspect was not sufficient to differentiate all the dentists in the study. A study on the profile of competences in collective health has found that the time since graduation did not interfere in the level of difficulty of exercising the profession in the public sector ${ }^{15}$.

The changes required must begin in the education and view of the world reproduced within the teaching academies, because it is in these spaces that formation of the possibilities of future employability of dentists and their social relevance certainly also begin. The great dilemma in dealing with sensitive subjects such as this is that all change brings with it a certain amount of "discomfort"21.

When one questions the impact that the pedagogical project has on the dental professional, various questions are raised with respect to the existence of a crisis in contemporary dentistry, or whether this crisis would be restricted to Dentistry considered market dentistry. To begin to answer this formulation, one could propose the inclusion in the entire academic conceptual architecture, of the notion that it is fundamental to form a work-force in Dentistry, with a view to the Brazil's Unified Health System, and within a logic of re-structuring oral health care ${ }^{19}$.

The salary made a distinction only between clusters 2 and 3 ( $p=0.033$ ), and may be considered an aspect of little importance in the description of the profile of this sample. The monthly income of dentists in public service has not been much evaluated in the literature ${ }^{18,22-23}$.

In the work market, the earnings of dentists fluctuate between 3 to 5 minimum-wages ${ }^{19}$. Dentists in clinical practice outside the South-eastern region are those 
that have the highest monthly incomes in private dental offices $^{14}$.

In a study in 2002, the authors found that the Family Health Strategy paid doctors and nurses higher salaries than the market values throughout Brazil. With regard to dentists, the salary is lower than the market value in all the regions of the country, with exception of the Northeast. Moreover, the mean salary is higher for doctors; that is, doctors are those who receive the highest salaries among the professionals that work in the strategy ${ }^{12}$.

With regard to the importance of the other variables in the division of the clusters, it was observed that the working hours, having a post-graduation course, and having done qualification and/or training were the most important aspects for defining the distinct profiles of the dentists in this study.

On a daily basis, dentists are exposed to long working hours ${ }^{24}$ and frequently work under unfavorable conditions ${ }^{25}$. However, some of the dentists in this study did not fulfill the working hours, which may indicate lack of commitment to work.

In spite of the majority of professionals having done post-graduation courses, the present study has limitations that did not allow one to find out whether an undergraduate education is sufficient for working in the Family Health Strategy. However, a lack of qualification of the professionals involved in health teams was observed, demonstrating a profile still focused on clinical activity ${ }^{26}$.

Considering the professional profile suggested by the new guideline circulars, continual qualification of the professionals already included in the system is necessary ${ }^{23}$ and to readjust dental courses to educate professionals qualified to meet social requirements ${ }^{16,27}$, in addition to the

\section{REFERENCES}

1. Pereira AC. Odontologia em saúde coletiva: planejando ações e promovendo a saúde. Porto Alegre: Artmed; 2003.

2. Cordón J. A construção de uma agenda para a saúde bucal coletiva. Cad Saúde Pública. 1997;13(3):557-63. doi: 10.1590/ S0102-311X1997000300033.

3. Souza TMS, Roncalli AG. Saúde bucal no Programa Saúde da família: uma avaliação do modelo assistencial. Cad Saúde Pública. 2007;23(11):2727-39. doi: 10.1590/S0102$311 \times 2007001100020$.

4. Brasil. Ministério da Saúde. Brasil sorridente: a saúde bucal levada a sério. Brasília: Ministério da Saúde; 2004. integration of teaching-services to include the competences of knowing, knowing-doing, and knowing how to be, with a view that questions the practice itself ${ }^{15}$.

\section{CONCLUSION}

Over the last few years, the Family Health Strategy has become the most important proposal for change in the model of health care in Brazil, with the main objective being to reorganize practice at the level of primary care. In this context in which oral health finds itself inserted, there are professionals with distinct profiles that must translate their actions into an effective practice that is coherent with that which is recommended by this strategy.

Family Health Strategy dentists differ with regard to the weekly working hours, post-graduation course and social participation in the municipality, with the time since graduation capable of being a crucial characteristic for pointing out these differences.

\section{Collaborators}

GCM MATTOS participated in the preparation, data collection, analysis, in discussion of the results and in writing the article. EF FERREIRA participated in writing the article and performed revision of the text. ACV CAMPOS participated in data analysis and in writing the article. ICG LEITE participated in the preparation, analysis and discussion of the results and in writing the article. RM GRECO coordinated the research and participated in writing the article.
5. Souza DS, Cury JA, Caminha JAN, Ferreira MA, Tomita NE, Narvai PC, et al. A Inserção da saúde bucal no Programa de Saúde da Família. Rev Bras Odontol. 2001;2:7-29.

6. Andrade KLC, Ferreira EF. Avaliação da inserção da odontologia no Programa Saúde da Família de Pompeu (MG): a satisfação do usuário. Ciênc Saúde Coletiva. 2006;11(1):123-30. doi: 10.1590/S1413-81232006000100020.

7. Martelli PJL, Cabral APS, Pimentel FC, Macedo CLSSV, Monteiro IS, Silva SF. Análise do modelo de atenção à saúde bucal em municípios do estado de Pernambuco. Ciênc. Saúde Coletiva. 2008;13(5):1669-74. doi: 10.1590/S141381232008000500030 . 
8. Hair JF, Black WC, Babin JB, Anderson RE, Tatham RL. Análise multivariada de dados. $6^{a}$ ed. Porto Alegre: Artmed; 2009.

9. Diniz D. Declaração de Helsinki: o prefácio do mundo. Gazeta Mercantil. 2000 Fev 14; Seção A-7.

10. Farias MR, Sampaio JJC. Papel do cirurgião-dentista na equipe de saúde da família. RGO - Rev Gaúcha Odontol. 2011;59(1):10915.

11. Campos ACV, Borges CM, Lucas SD, Vargas AMD, Ferreira EF. Public service dental actions in a small town. RGO - Rev Gaúcha Odontol. 2012;60(1):27-32.

12. Carvalho CL, Girardi SB. Agentes institucionais e modalidades de contratação de pessoal no Programa Saúde da Família no Brasil: relatório de pesquisa. Belo Horizonte: Ministério da Saúde; 2002 [citado 2012 Out 10]. Disponível em: <https://www.nescon. medicina.ufmg.br/biblioteca/imagem/2437.pdf>.

13. Diógenes VCN, Souza GCA, Emiliano CBG, Lima Júnior JF, Suliano AA. Teaching-learning process in times of the Unified Health System (SUS): training of faculty and dental surgeons in Brazil. Rev Odonto Ciênc. 2010;25(1):92-6. doi: 10.1590/S198065232010000100019.

14. Bastos JRM, Aquilante AG, Almeida BS, Lauris JRP, Bijella VT. Análise do perfil profissional de cirurgiões-dentistas graduados na Faculdade de Odontologia de Bauru - USP entre os anos de 1996 e 2000. J Appl Oral Sci. 2003;11(4):283-9. doi: 10.1590/ S1678-77572003000400003.

15. Costa ICC, Araújo MNT. Definição do perfil de competências em saúde coletiva a partir da experiência de cirurgiões-dentistas atuantes no serviço público. Ciênc Saúde Coletiva. 2011;16(Supl. 1):1181-9. doi: 10.1590/S1413-81232011000700050.

16. Pinheiro FMC, Nóbrega-Therrien SM, Almeida MEL, Almeida MI. A formação do cirurgião-dentista e a promoção de saúde no PSF. Rev Odontol UNESP. 2008;37(1):69-77.

17. Pinheiro FMC, Nóbrega-Therrien SM, Almeida MEL, Almeida MI. A formação do cirurgião-dentista no Brasil: contribuições de estudos para a prática da profissão. RGO - Rev Gaúcha Odontol. 2009;57(1):99-106

18. Chaves SCL, Silva LMV. As práticas profissionais no campo público de atenção à saúde bucal: o caso de dois municípios da Bahia. Ciênc Saúde Coletiva. 2007;12(6):1697-710. doi: 10.1590/S1413-81232007000600031.

19. Moysés SJ. Políticas de saúde e formação de recursos humanos em Odontologia: os cursos de Odontologia devem avançar para um projeto pedagógico construído coletivamente, centrado no aluno como sujeito da aprendizagem e no professor como mediador do processo ensino-aprendizagem. Rev ABENO. 2004;4(1):30-7.
20 Narvai PC. Odontologia e saúde bucal coletiva. São Paulo: Hucitec; 1994.

21. Moysés SJ. A humanização da educação em Odontologia. Proposições/UNICAMP. 2003;14(1):40-74.

22. Pereira AC, Mialhe FL, Pereira SM, Meneghim MC. O mercado de trabalho odontológico em saúde coletiva: possibilidades e discussões. Arq Odontol. 2010;46(4):232-9.

23. Aerts D, Abegg C, Cesa K. O papel do cirurgião-dentista no Sistema Único de Saúde. Ciênc Saúde Coletiva. 2004;9(1):1318. doi: 10.1590/S1413-81232004000100013.

24. Carvalho FS, Maia Júnior AF, Carvalho CAP, Sales Peres A, Bastos JRM, Sales Peres SHC. Qualidade de vida do cirurgião-dentista. Rev Odontol UNESP. 2008;37(1):65-8.

25. Costa ACO, Moimaz SAS, Garbin AJl, Garbin CAS. Plano de carreira, cargos e salários: ferramenta favorável à valorização dos recursos humanos em saúde pública. Odontol Clín-Cient. 2010;9(2)119-23.

26. Araújo YP, Dimenstein M. Estrutura e organização do trabalho do cirurgião-dentista no PSF de municípios do Rio Grande do Norte. Ciênc Saúde Coletiva. 2006;11(1):219-27. doi: 10.1590/ S1413-81232006000100031

27. Kriger L, Morita MC. Mudanças nos cursos de Odontologia e a interação com o SUS. Rev ABENO. 2004;4:17-21. 